\title{
Investigation of $\mathrm{Li}^{+}$Cation Coordination and Transportation, by Molecular Modeling and NMR Studies, in a LiNTf ${ }_{2}$-Doped lonic Liquid-Vinylene Carbonate Mixture
}

Ewelina Bolimowska, ${ }^{\dagger, \|}$ Franca Castiglione, ${ }^{\ddagger}$ Julien Devemy ${ }^{\S}$ Helene Rouault, ${ }^{\|}$Andrea Mele, ${ }^{*}$,

Agílio A. H. Pádua, ${ }^{\S(0)}$ and Catherine C. Santini*, ${ }^{\dagger \dagger}$

†Université de Lyon, Institut de Chimie de Lyon, UMR 5265 CNRS-C2P2, 43 Boulevard du 11 Novembre 1918, 69616
Villeurbanne, France

${ }^{\ddagger}$ Department of Chemistry, Materials and Chemical Engineering “G. Natta”, Politecnico di Milano, Piazza L. da Vinci 32,20133 Milano, Italy

${ }^{\S}$ Institut de Chimie de Clermont-Ferrand, Université Clermont Auvergne, CNRS, 24 Avenue Blaise Pascal, 63178 Aubière, France

"CEA-Liten, 17, rue des Martyrs, 38054 Grenoble Cedex 9, France

Supporting Information

ABSTRACT: To increase the safety and stability of lithiumion batteries, the development of electrolytes based on ionic liquids (ILs) has gained a lot of attention in recent years. However, with graphite electrodes, neat ILs afford weak cycling performance in the absence of organic additives (e.g., vinylene carbonate, $\mathrm{VC}$ ). The potential formation of a $\left[\mathrm{Li}^{+}\right]-$ $\mathrm{O}_{\mathrm{VC}}$ interaction/coordination could have a major influence on the observed electrochemical behavior of Li-ion batteries. On a specific electrolyte, 1-hexyl-3-methylimidazolium bis(trifluoromethanesulfonyl)imide $\left[\mathrm{C}_{1} \mathrm{C}_{6} \mathrm{Im}\right]\left[\mathrm{NTf}_{2}\right]$ in association with $\mathrm{Li}\left[\mathrm{NTf}_{2}\right]\left(1 \mathrm{~mol} \mathrm{~L}{ }^{-1}\right)$ and $\mathrm{VC}$, we performed NOESY, $\left\{{ }^{1} \mathrm{H}-{ }^{7} \mathrm{Li}\right\}$ HOESY correlations, and pulsed field gradient spin-echo NMR measurements, combined with molecular dynamics simulations to determine whether such an interaction/coordination between $\mathrm{VC}$ and $\mathrm{Li}^{+}$ions is noticeable. $\left\{{ }^{7} \mathrm{Li}-{ }^{1} \mathrm{H}\right\}$ HOESY experiment shows the vicinity of $\mathrm{VC}$ with $\left[\mathrm{Li}^{+}\right]$cation, and strong correlations and association between $\left[\mathrm{Li}^{+}\right]$and VC are observed in intense first peaks in radial distribution functions and quantified by the coordination numbers in the first solvation shell between $\left[\mathrm{Li}^{+}\right]$and the carbonyl oxygen atom of VC.

\section{INTRODUCTION}

Lithium-ion batteries are extensively used as a power source for consumer electronics, such as mobile phones and laptops, because of their high energy density. ${ }^{1}$ They are the mostpromising option for the next generation of the hybrid and electric vehicles. For this purpose, extensive studies are focused to increase their safety, due to the use of a flammable organic carbonate electrolyte, and decrease their capacity loss resulting from the reactions of the electrolyte on the electrode surface. To develop safer Li-ion batteries, the development of electrolytes that are more suitable and additives, which can stabilize the solid electrolyte interfaces (SEIs), is ongoing.

The electrolytes derived from imidazolium-based ionic liquids (ILs) associated with bis(trifluoromethanesulfonyl)imide anion $\left[\mathrm{NTf}_{2}{ }^{-}\right]$have gained a lot of attention because of their thermal and electrochemical stability, flame-retardant performance, and higher molar conductivity. A challenge in their application is their limited lithium-ion transport properties related to their

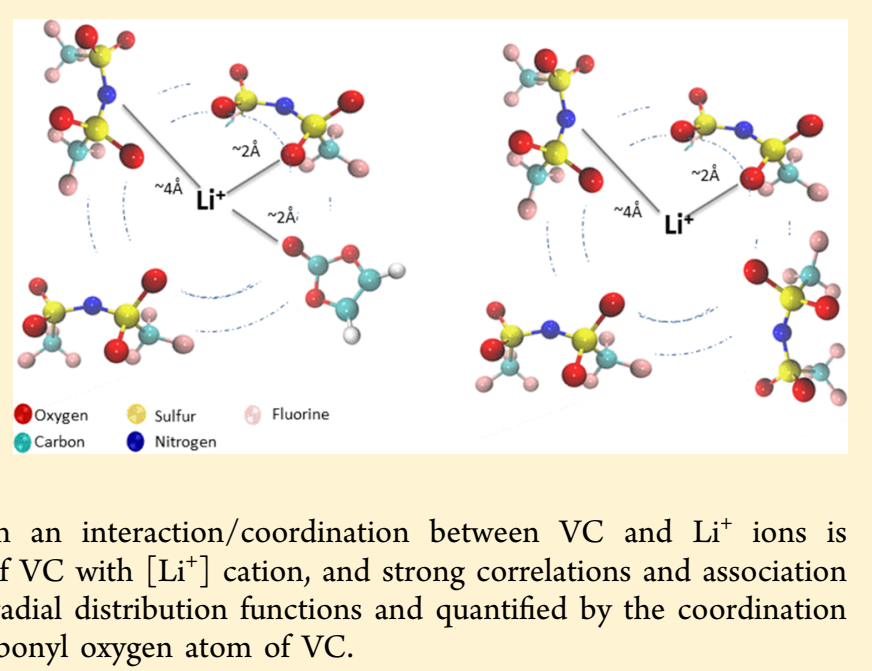

high viscosity, implying low cycling and power delivery for ILbased batteries. $^{2-5}$

Previous studies have shown that the addition of organic carbonate additives (OA) to IL electrolytes is crucial to improve the battery performance. ${ }^{6-10}$ It is largely admitted that this enhancement is related to the decomposition of the carbonate on the negative electrode ensuring the formation of a stable SEI. ${ }^{3,6}$

Additionally, the addition of OA enhances the transport properties of the electrolytes because of the reduction of the viscosity of the medium. ${ }^{5}$ Nevertheless, the decrease of selfdiffusion coefficient $(D)$ of the ions was not proportional to the reduction of the viscosity. For instance, the viscosity of the electrolyte based on $\left[\mathrm{Pyr}_{13}\right]\left[\mathrm{NTf}_{2}\right] / / \mathrm{Li}\left[\mathrm{NTf}_{2}\right]$ decreases by a factor $\sim 2$ on the addition of $20 \mathrm{~mol} \%$ ethylene carbonate (EC)

Received: May 31, 2018

Revised: August 17, 2018

Published: August 17, 2018 
or tetraglyme (Gly) compared to the viscosity of $\left[\mathrm{Pyr}_{13}\right]$ $\left[\mathrm{NTf}_{2}\right] / / \mathrm{Li}\left[\mathrm{NTf}_{2}\right]$. However, compared to that of a nondoped medium, the self-diffusion coefficient of $\left[\mathrm{Li}^{+}\right]\left(D_{\mathrm{Li}^{+}}\right)$increases by a factor of 1.6 with EC and by a factor of 4 with Gly. Viscosity is not the only determining factor of $\left[\mathrm{Li}^{+}\right]$transport. ${ }^{6,7}$

The comparison of Raman spectra of the electrolyte $\left[\mathrm{C}_{1} \mathrm{C}_{2} \mathrm{Im}\right]\left[\mathrm{NTf}_{2}\right] / / \mathrm{Li}\left[\mathrm{NTf}_{2}\right]$ and one diluted with OA (EC, vinylene carbonate (VC), acetonitrile (AN)) provides valuable data to prove a modification in the coordination environment of ions in the presence of OA. ${ }^{11,12}$ Indeed, the presence of OA can influence both the mobility and the coordination shell of $\left[\mathrm{Li}^{+}{ }^{6,7,11,12}\right.$

As mentioned by Borodin et al., ${ }^{12-14}$ in $\mathrm{IL} / \mathrm{LiNTf}_{2}$ medium, $\left[\mathrm{Li}^{+}\right]$is coordinated on an average by slightly less than four oxygen atoms from $\left[\mathrm{NTf}_{2}^{-}\right]$anion, and its transport is mainly dependent on $\left[\mathrm{NTf}_{2}^{-}\right]$exchange in the first coordination shell. ${ }^{11-14}$ In carbonate electrolytes (e.g., EC, with $\mathrm{LiPF}_{6}$ ), $\left[\mathrm{Li}^{+}\right]$ preferentially solvated by carbonyl rather than ethereal oxygen of carbonate shows a similar diffusion mechanism. ${ }^{15}$ However, most of the literature data are concerned with simulation and spectroscopy data on the coordination sphere and the transportation of $\left[\mathrm{Li}^{+}\right]$in electrolytes based on neat ILs or pure carbonate. To the best of our knowledge, few systematic studies on a IL/OA mixture investigated the coordination shell and the transportation of $\left[\mathrm{Li}^{+}\right]$.

Recently, our group improved electrolytes based on imidazolium ionic liquids (1-hexyl-3-methylimidazolium bis(trifluoromethanesulfonyl)imide) $\left(\left[\mathrm{C}_{1} \mathrm{C}_{6} \mathrm{Im}\right]\left[\mathrm{NTf}_{2}\right]\right)$ with or without $\mathrm{VC}$, and in association with $\mathrm{Li}\left[\mathrm{NTf}_{2}\right]$, for graphite secondary batteries. ${ }^{10}$ The intercalation-deintercalation of $\left[\mathrm{Li}^{+}\right]$in Cgr electrode was observed only in the presence of VC with an optimum at 5 vol \%. ${ }^{10}$ Recently, we reported that VC has a major influence on the Cgr electrode wettability ${ }^{16}$ and on the electrochemical behavior of these batteries. ${ }^{17}$

To further understand these results, this paper outlines the effects of VC on the mobility and the coordination shell of $\left[\mathrm{Li}^{+}\right]$. The local structure and the transport properties of $\left[\mathrm{C}_{1} \mathrm{C}_{6} \mathrm{Im}\right]$ $\left[\mathrm{NTf}_{2}\right]$-based solutions, described in Table 1 , were studied by

Table 1. Investigation of Neat-Ionic-Liquid-Based and IonicLiquid-Based Electrolytes

\begin{tabular}{cl} 
name & \multicolumn{1}{c}{ components } \\
sample 1 & neat $\left[\mathrm{C}_{1} \mathrm{C}_{6} \operatorname{Im}\right]\left[\mathrm{NTf}_{2}\right]$ \\
sample 2 & {$\left[\mathrm{C}_{1} \mathrm{C}_{6} \mathrm{Im}\right]\left[\mathrm{NTf}_{2}\right]+5 \mathrm{vol} \% \mathrm{VC}$} \\
sample 3 & {$\left[\mathrm{C}_{1} \mathrm{C}_{6} \mathrm{Im}\right]\left[\mathrm{NTf}_{2}\right]+1 \mathrm{~mol} \mathrm{~L}^{-1} \mathrm{LiNTf}_{2}$} \\
sample 4 & {$\left[\mathrm{C}_{1} \mathrm{C}_{6} \mathrm{Im}\right]\left[\mathrm{NTf}_{2}\right]+1 \mathrm{~mol} \mathrm{~L}^{-1} \mathrm{LiNTf}_{2}+5 \mathrm{vol} \% \mathrm{VC}$}
\end{tabular}

NMR using $\left\{{ }^{1} \mathrm{H}-{ }^{7} \mathrm{Li}\right\},\left\{{ }^{1} \mathrm{H}-{ }^{19} \mathrm{~F}\right\}$ NOE correlations (HOESY), and pulsed field gradient spin-echo (PGSE) NMR. The molecular dynamic simulations of both electrolytes (Table 1, samples 3 and 4) provided a further detailed microscopic picture of dynamical and structural properties of $\left[\mathrm{Li}^{+}\right]$with or without VC.

\section{EXPERIMENTAL AND THEORETICAL METHODS}

Materials. 1-Methylimidazole (>99\%, Aldrich) was distilled prior to use. Chlorohexane (>99\%, Aldrich), vinylene carbonate (>99\%, Aldrich), and bis(trifluoromethanesuflonyl)imide lithium salt ( $>99 \%$, Solvionic) were used without further purification

Synthesis of 1-Hexyl-3-methylimidazolium bis(trifluoromethylsulphonyl)imide $\left[\mathrm{C}_{1} \mathrm{C}_{6} \mathrm{Im}\right]\left[\mathrm{NTf}_{2}\right]$. A solu- tion of lithium bis(trifluorosulphonylimide) $\operatorname{LiNTf}_{2}(50 \mathrm{~g}, 0.17$ $\mathrm{mol})$ in water $(50 \mathrm{~mL})$ was added to a solution of 1-hexyl-3methylimidazolium chloride $\left[\mathrm{C}_{1} \mathrm{C}_{6} \mathrm{Im}\right][\mathrm{Cl}](30.4 \mathrm{~g}, 0.17 \mathrm{~mol})$ in water $(100 \mathrm{~mL})$. The solution was stirred for $2 \mathrm{~h}$ at room temperature and then dichloromethane $(50 \mathrm{~mL})$ was added and the mixture transferred to a separating funnel. The lower phase was collected and washed repetitively with water $(8 \times 100 \mathrm{~mL})$ until no chloride traces remained in the washings (tested with silver nitrate solution). The ionic liquid in dichloromethane was purified through an alumina column, and the solvent was removed in vacuum giving a colorless viscous liquid. After several washings with water, followed by $\mathrm{AgNO}_{3}$ tests, the absence of residual chloride $(<0.5 \%)$ was assessed by highresolution mass spectroscopy and cyclic voltammetry (CV) measurements. The CV measurements were carried out in a one-compartment three-electrode cell using a home-made ionicliquid-based $\mathrm{Ag} / \mathrm{Ag}^{+}$reference electrode. No irreversible oxidation waves above $1.5 \mathrm{~V}$ assigned to residual chloride were observed. ${ }^{18}$ After drying under vacuum $\left(10^{-5} \mathrm{mbar}\right)$ for 24 $\mathrm{h}$ at $40{ }^{\circ} \mathrm{C}$, the water content was lowered to $60 \mathrm{ppm}$ (mass ratio), as assessed by Karl Fisher coulometric titration.

Electrolytes. The electrolytes were prepared by adding LiNTf $_{2}\left(1 \mathrm{~mol} \mathrm{~L}^{-1}\right)$ in a well-stirred IL at room temperature, followed by storage in an argon-filled glovebox.

NMR Measurements. The ${ }^{1} \mathrm{H}$ and ${ }^{19} \mathrm{~F}$ NMR experiments were performed on a Bruker Avance 500 spectrometer operating at $500.13 \mathrm{MHz}$ proton frequency equipped with a QNP four nuclei switchable probe. The ${ }^{7} \mathrm{Li}$ experiments were carried out on a Bruker DRX 500 spectrometer equipped with a broadband probe. The experimental conditions were as follows: pulsed gradient spin-echo (PGSE) NMR technique was used to measure the individual self-diffusion coefficients $D$ for $\mathrm{Li}^{+}$, $\left[\mathrm{C}_{1} \mathrm{C}_{6} \mathrm{Im}^{+}\right],\left[\mathrm{NTf}_{2}^{-}\right]$, and $\mathrm{VC}$ species by observations in the ${ }^{7} \mathrm{Li}$, ${ }^{1} \mathrm{H}$, and ${ }^{19} \mathrm{~F}$ frequency domains, respectively. In each experiment, a series of 32 spectra with $16 \mathrm{~K}$ points were recorded using a relaxation delay D1 of $10 \mathrm{~s}$ for sample equilibration. A pulsed gradient unit capable of producing magnetic field pulse gradients of $53 \mathrm{G} \mathrm{cm}^{-1}$ in the $z$-direction was used, and the pulse gradients were incremented from 2 to $95 \%$ of the maximum gradient strength in a linear ramp. The durations of the magnetic field pulse gradient $(\delta)$ and observation time $(\Delta)$ were optimized for each sample to obtain complete dephasing of the signals with the maximum gradient strength. For the investigated samples, $\delta$ values were in the range of $2-3 \mathrm{~ms}$, while $\Delta$ values were in the range of $0.5-0.8$ and $0.6-0.8 \mathrm{~s}$ for ${ }^{1} \mathrm{H}$ and ${ }^{19} \mathrm{~F}$ experiments, respectively. Measurements with variable temperature (in the range of $305-335 \mathrm{~K}$, in a step of $5 \mathrm{~K}$ ) were achieved for all of the investigated samples. In the temperature range $T=305-315 \mathrm{~K}$, the BPP-LED pulse sequence was used, while the double stimulated echo sequence is required at a higher temperature ( $T$ $\geq 320 \mathrm{~K}$ ) for convection compensation. Data analysis and fitting of the experimental signal decay were performed using Bruker software (Figures SI-1 to SI-3). The precision of the reported diffusion coefficients is within $10 \%$.

The two-dimensional-NMR homonuclear and heteronuclear correlation experiments (NOESY and HOESY, respectively) were run only on samples 3 and 4 . The $\left\{{ }^{1} \mathrm{H}-{ }^{1} \mathrm{H}\right\}$ NOESY spectra were recorded with a sweep width of $10 \mathrm{ppm}, 16$ scans for each of the 512 increments, and a mixing time of $300 \mathrm{~ms}$. The heteronuclear $\left\{{ }^{1} \mathrm{H}-{ }^{7} \mathrm{Li}\right\}$ NOE correlation experiments (HOESY) were carried out using the inverse-detected pulse sequence with 512 increments in the $\mathrm{t} 1$ dimension, 16 scans for 
(a)

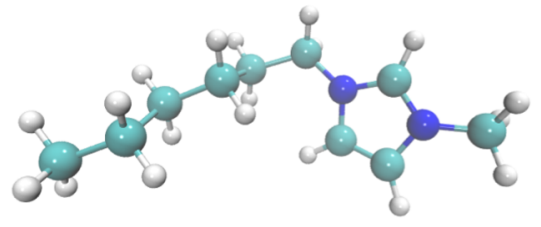

(b)

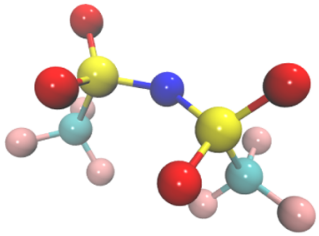

(c)

Figure 1. Molecular structures of $(\mathrm{a}) \mathrm{C}_{1} \mathrm{C}_{6} \mathrm{Im}^{+},(\mathrm{b}) \mathrm{NTf}_{2}{ }^{-}$, and (c) vinylene carbonate are shown. The atoms are colored as follows: cyan = carbon, red $=$ oxygen, blue $=$ nitrogen, gray $=$ hydrogen, pink $=$ fluorine, and yellow $=$ sulfur .

each experiment, and a mixing time of $40,70 \mathrm{~ms}$. The temperature was set and controlled at $305 \mathrm{~K}$.

Density. Experimental density measurements were performed using a U-shaped vibrating-tube densimeter (Anton Paar, model DMA 5000M) operating in a static mode. All measurements were performed at atmospheric pressure and 298.15-353.15 K. The temperature was maintained constant within $\pm 0.01 \mathrm{~K}$. The uncertainty of the density measurements was estimated as $\pm 0.1 \mathrm{~kg} \mathrm{~m}^{-3}$. During the density measurement, the sample was exposed to air. Therefore, when the experiment was finished, the measurement at $298.15 \mathrm{~K}$ was reproduced to verify that the sample density did not change with time. ${ }^{19}$

Viscosity. All of the viscosity measurements were performed with an Anton Paar AMVn rolling ball viscosimeter at atmospheric pressure and 298.15-353.15 K. The temperature was controlled within $0.01 \mathrm{~K}$ with a built-in Peltier device. The measurements were completed using a $1.8 \mathrm{~mm}$ diameter capillary tube that was calibrated as a function of temperature and angle of measurement using standard viscosity oils from CANNON. The overall uncertainty of the viscosity was estimated as $\pm 1.5 \% .^{20}$

Molecular Dynamics (MD) Methodology. The potential energy of the system was modeled using the following standard functional form, eq 1

$$
\begin{aligned}
\Phi_{\text {tot }}= & \sum_{\text {bonds }} k_{\mathrm{b}}\left(r-r_{0}\right)^{2}+\sum_{\text {angles }} k_{\theta}\left(\theta-\theta_{0}\right)^{2}+ \\
& \sum_{\text {dihedrals }} \sum_{n} k_{\chi}[1+\cos (n \chi-\delta)]+ \\
& \sum_{\text {impropers }} k_{\psi}\left(\psi-\psi_{0}\right)^{2}+ \\
& \sum_{i=1}^{N-1} \sum_{j>1}^{N}\left\{4 \epsilon_{i j}\left[\left(\frac{\sigma_{i j}}{r_{i j}}\right)^{12}-\left(\frac{\sigma_{i j}}{r_{i j}}\right)^{6}\right]+\frac{q_{i} q_{j}}{r_{i j}}\right\}
\end{aligned}
$$

where the total energy is expressed in terms of bond stretching, angle bending, dihedral torsion, improper dihedral torsion, and van der Waals and electrostatic interactions. ${ }^{21}$ Electrostatic partial charges on the atomic sites of $\mathrm{VC}$ were calculated using $\mathrm{ab}$ initio methods, given in Table SI- 1 . The geometry of VC was optimized at the level HF/6-316(d), and the electron density was calculated for this geometry at the MP2/cc-pVTZ level. The atomic partial charges were computed using the CHelpG electrostatic surface potential method. ${ }^{22}$ The other terms on the force field were obtained from the literature on optimized potential for liquid simulations all-atom parameters (LennardJones sites and torsion energy profiles) and AMBER (bonds and angles). ${ }^{23}$ The force field of VC was validated by calculation of the density and enthalpy of vaporization using MD simulations and comparison with the experiment, given in Table SI-2.
The ionic liquid was modeled by the CL\&P force field. ${ }^{24} \mathrm{~A}$ mixture of $\left[\mathrm{C}_{1} \mathrm{C}_{6} \mathrm{Im}\right]\left[\mathrm{NTf}_{2}\right]$ with $\operatorname{LiNTf}_{2}\left(1 \mathrm{~mol} \mathrm{~L}^{-1}\right)$ and VC (5 vol \%) was simulated in a periodic cubic box. An initial configuration was set up with $180\left[\mathrm{C}_{1} \mathrm{C}_{6} \mathrm{Im}^{+}\right], 60\left[\mathrm{Li}^{+}\right], 240$ $\left[\mathrm{NTf}_{2}^{-}\right]$ions, and $48 \mathrm{VC}$ molecules using the software packmol. ${ }^{25}$ The molecular structures are represented in Figure 1.

The cutoff distance for nonbonded interactions was $12 \AA$, and long-range interactions were handled using the particle-particle particle-mesh Ewald summation method as implemented in the LAMMPS molecular dynamics software. ${ }^{26}$ Covalent bonds involving $\mathrm{H}$ atoms were constrained using the SHAKE technique, allowing for a time step of $2 \mathrm{fs}$.

The calculation of individual atomic partial charges for ILs provides the key for a successful modeling of their physical and chemical properties. Reduction of the ionic net charge of ions in ILs is necessary for the proper description of their dynamic properties since with integer charges the dynamics tends to be too slow. Agreement with the experiment in general is better if the total charge of univalent ions was scaled to $\pm 0.8 \mathrm{e},{ }^{27}$ with the partial charges on each atom uniformly scaled to achieve this total ionic charge. The system was equilibrated for $20 \mathrm{~ns}$ at 315 , 335 , and $355 \mathrm{~K}$.

\section{RESULTS AND DISCUSSION}

Density and Viscosity Measurements. Density $(\rho / \mathrm{kg}$ $\left.\mathrm{m}^{-3}\right)$ and viscosity $(\eta / \mathrm{mPa} s)$ of samples 3 and 4 and conductivity $\kappa\left(\mathrm{S} \mathrm{m}^{-1}\right)$ of samples $1-4$ as a function of temperature were measured. For all samples, the density (Table SI-3 and Figure SI-4) and the viscosity (Table SI-4 and Figure SI-5) decrease with the increasing temperature. As generally reported, the lithium-salt-doped solutions present a higher viscosity as the neat ionic liquid. ${ }^{28}$ In the presence of VC, the density is relatively unchanged (Table SI-4.).

Conversely, the viscosity was found to decrease by a factor of $\sim 1.5$ for sample 4 compared to that of sample 3 , regardless of the temperature. This finding is in line with what was reported for a mixture of $\left[\mathrm{C}_{1} \mathrm{C}_{6} \mathrm{Im}\right]\left[\mathrm{NTf}_{2}\right]$ and 1-octene taken as a model system for IL and organic additive. ${ }^{28}$ The Arrhenius plot and the linear fittings of samples 3 and 4, Table SI-4, allow the determination of the activation energy for viscosity $E_{\mathrm{a}}$ equal to 37 and $33.4 \mathrm{KJ} \mathrm{mol}^{-1}$, respectively.

Ionic conductivity is related to the degree of dissociation, charge number, and ionic mobility of the ions. Although ILs are composed entirely of ions, they are, in general, significantly less conductive than concentrated organic electrolytes and aqueous electrolytes. ${ }^{28}$ The values of the conductivity $\left(\kappa, \mathrm{S} \mathrm{m}^{-1}\right)$ for the four examined samples are reported, in the $T$ span of 298-353 $\mathrm{K}$, in Table SI-5. For all samples, $\kappa$ decreases significantly on passing from the IL to the corresponding IL added to $\operatorname{LiNTf}_{2}$, that is, on passing from samples 1 to 3 and from samples 2 to 4 . For the sake of clarity, at $303 \mathrm{~K}$ the conductivity values in $\mathrm{S} \mathrm{m}^{-1}$ for samples 1 and 3 are 0.34 and 0.11 , respectively, while those of samples 2 and 4 are 0.34 and 0.24 , respectively. For all 
Table 2. Diffusion Coefficient, $D$, Values $\left(\mathrm{m}^{2} \mathrm{~s}^{-1}\right) \times 10^{-11}$ at Different Temperatures for All of the Ions in $\left[\mathrm{C}_{1} \mathrm{C}_{6} \mathrm{Im}\right]\left[\mathrm{NTf} \mathrm{f}_{2}\right]$ and $\left[\mathrm{C}_{1} \mathrm{C}_{6} \mathrm{Im}\right]\left[\mathrm{NTf}_{2}\right] / / \mathrm{VC}(5 \% \mathrm{vol})$ and the Electrolytes $\left[\mathrm{C}_{1} \mathrm{C}_{6} \mathrm{Im}\right]\left[\mathrm{NTf}_{2}\right] / / \mathrm{LiNTf}_{2}\left(1 \mathrm{~mol} \mathrm{~L}^{-1}\right)$ and $\left[\mathrm{C}_{1} \mathrm{C}_{6} \mathrm{Im}\right]\left[\mathrm{NTf}_{2}\right] / / \mathrm{VC}(5 \%$ vol) $/ / \operatorname{LiNTf}_{2}\left(1 \mathrm{~mol} \mathrm{~L}^{-1}\right)$

\begin{tabular}{|c|c|c|c|c|c|c|c|}
\hline \multicolumn{4}{|c|}{ sample $1\left[\mathrm{C}_{1} \mathrm{C}_{6} \mathrm{Im}\right]\left[\mathrm{NTf}_{2}\right]$} & \multicolumn{4}{|c|}{ sample $2\left[\mathrm{C}_{1} \mathrm{C}_{6} \mathrm{Im}\right]\left[\mathrm{NTf}_{2}\right] / / \mathrm{VC}$ (5\% vol) } \\
\hline$T(\mathrm{~K})$ & \multicolumn{2}{|c|}{$\left[\mathrm{C}_{1} \mathrm{C}_{6} \mathrm{Im}^{+}\right]$} & {$\left[\mathrm{NTf}_{2}^{-}\right]$} & {$\left[\mathrm{C}_{1} \mathrm{C}_{6} \mathrm{Im}^{+}\right]$} & \multicolumn{2}{|r|}{$\left[\mathrm{NTf}_{2}^{-}\right]$} & $\mathrm{VC}$ \\
\hline 305 & \multicolumn{2}{|c|}{2.57} & 2.02 & 3.45 & \multicolumn{2}{|r|}{2.92} & 10.9 \\
\hline 310 & \multicolumn{2}{|c|}{3.28} & 2.9 & 4.35 & \multicolumn{2}{|r|}{3.98} & 13.6 \\
\hline 315 & \multicolumn{2}{|c|}{4.05} & 3.47 & 5.38 & \multicolumn{2}{|r|}{4.95} & 16.6 \\
\hline 320 & \multicolumn{2}{|c|}{4.9} & 4.45 & 6.3 & \multicolumn{2}{|r|}{5.92} & 18.6 \\
\hline 325 & \multicolumn{2}{|c|}{5.78} & 5.55 & 7.45 & \multicolumn{2}{|r|}{7.11} & 22 \\
\hline 330 & \multicolumn{2}{|c|}{6.9} & 6.57 & 8.78 & \multicolumn{2}{|r|}{8.03} & 26 \\
\hline 335 & \multicolumn{2}{|c|}{8.27} & 7.4 & 10.22 & \multicolumn{2}{|r|}{9.11} & 30.7 \\
\hline \multicolumn{4}{|c|}{ sample $3\left[\mathrm{C}_{1} \mathrm{C}_{6} \operatorname{Im}\right]\left[\mathrm{NTf}_{2}\right] / / \operatorname{LiNTf}_{2}\left(1 \mathrm{~mol} \mathrm{~L}^{-1}\right)$} & \multicolumn{4}{|c|}{ sample $4\left[\mathrm{C}_{1} \mathrm{C}_{6} \mathrm{Im}\right]\left[\mathrm{NTf}_{2}\right] / / \mathrm{VC}(5 \% \mathrm{vol}) / / \mathrm{LiNTf}_{2}\left(1 \mathrm{~mol} \mathrm{~L}^{-1}\right)$} \\
\hline$T(\mathrm{~K})$ & {$\left[\mathrm{C}_{1} \mathrm{C}_{6} \mathrm{Im}^{+}\right]$} & {$\left[\mathrm{NTf}_{2}^{-}\right]$} & {$\left[\mathrm{Li}^{+}\right]$} & {$\left[\mathrm{C}_{1} \mathrm{C}_{6} \mathrm{Im}^{+}\right]$} & {$\left[\mathrm{NTf}_{2}^{-}\right]$} & {$\left[\mathrm{Li}^{+}\right]$} & $\mathrm{VC}$ \\
\hline 305 & 1.1 & 0.66 & 0.53 & 1.35 & 0.98 & 0.61 & 3.27 \\
\hline 310 & 1.47 & 0.80 & 0.67 & 2.12 & 1.37 & 0.77 & 5.11 \\
\hline 315 & 1.84 & 1.23 & 0.95 & 2.75 & 1.55 & 1.22 & 7.05 \\
\hline 320 & 2.44 & 1.67 & 1.16 & 3.5 & 2.1 & 2.03 & 9.4 \\
\hline 325 & 3.08 & 2.26 & 1.42 & 4.6 & 3.39 & 2.71 & 12.8 \\
\hline 330 & 3.8 & 2.6 & 1.68 & 5.3 & 4.5 & 3.14 & 15.2 \\
\hline 335 & 4.5 & 3.21 & 2.32 & 6.6 & 5.8 & 3.45 & 17.3 \\
\hline
\end{tabular}

temperatures, the addition of VC to the neat IL does not induce significant changes in the conductivity values (compare the data of samples 1 and 2 in Table SI-5), as expected in the case of ideal mixing of the ionic liquid with VC. This finding is consistent with the tendency of $\mathrm{VC}$ to fill the interstices among ions, thus showing a more efficient packing compared to that of ideal solutions. It is worthy of note that such behavior is in line with the prediction, obtained by $\mathrm{MD}$ simulations, of the mixing properties of ethylene carbonate (EC) in $N$-methyl- $N$ propylpyrrolidinium $\left(\right.$ pyr $\left._{13}\right) \mathrm{NTf}_{2}{ }^{13}$ In contrast, the addition of VC does influence the conductivity of the systems containing IL and LiNTf 2 . The data in Table SI-5 clearly shows that, for all of the examined temperatures, the conductivity of sample 4 is twice that of sample 3, This effect cannot be entirely accounted for by viscosity changes in the two systems, as the viscosity of sample 4 decreases by a factor of 1.5 with respect to sample 3 , as indicated in Table SI-4.

NMR Measurements. The self-diffusion coefficients of IL cations, IL anions, and lithium ions were measured independently by PGSE-NMR experiments in the ${ }^{1} \mathrm{H},{ }^{19} \mathrm{~F}$, and ${ }^{7} \mathrm{Li}$ frequency domains, respectively. Data analysis and calculation of the self-diffusion coefficients from the NMR intensity signal decay $I$ as a function of the increasing gradient strength were performed according to eq 2

$$
I=I_{0} \exp \left[-(\gamma g \delta)^{2} D\left(\Delta-\frac{\delta}{3}\right)\right]
$$

where $I_{0}$ is the echo intensity without field gradient, $\gamma$ is the gyromagnetic ratio of the observed nucleus, $g$ is the magnetic field gradient strength, $\delta$ is the duration of the field gradient with magnitude $g$, and $\Delta$ is the observation time.

The resulting diffusion coefficient, $D$, values $\left(\mathrm{m}^{2} \mathrm{~s}^{-1}\right)$ are reported in Table 2 for all of the investigated samples (1-4) and in the full range of temperatures. The observed trend for the diffusion of ions when we compare sample 1 with sample 2 is $D\left[\mathrm{NTf}_{2}^{-}\right]<D\left[\mathrm{C}_{1} \mathrm{C}_{6} \mathrm{Im}^{+}\right]<D[\mathrm{VC}]$. The trend is maintained in the full range of temperatures explored in the present work. The relationship $D_{\text {anion }}<D_{\text {cation }}$ is widely reported in the literature of ionic liquids. ${ }^{29}$ In general, the observation of $D_{\text {cation }} / D_{\text {anion }} \neq 1$ could be related to ion pairing or, more in general, to the formation of larger aggregates. This point has been clearly outlined by D'Agostino et al. who showed that the reduced mobility of the anion compared to that of the cation in model $\left[\mathrm{C}_{1} \mathrm{C}_{2} \mathrm{Im}\right]\left[\mathrm{CH}_{3} \mathrm{COO}\right]$ can be related to aggregation phenomena and that "anions do not diffuse as isolated species but as a part of larger ion aggregates". ${ }^{30}$ Accordingly, our findings are consistent with a higher degree of organization of the anions compared to that of the cations.

As generally reported in the literature, ${ }^{31,32}$ the diffusion coefficients in samples 3 and 4 follow the general trend $D\left[\mathrm{Li}^{+}\right]<$ $D\left[\mathrm{NTf}_{2}^{-}\right]<D\left[\mathrm{C}_{1} \mathrm{C}_{6} \mathrm{Im}^{+}\right]$. This suggests that Li-anion aggregates $\left[\mathrm{Li}\left(\mathrm{NTf}_{2}\right)_{n}\right]^{(n-1)-}$ are still present in both samples. 14,33

The main purpose of diffusion measurements is to work out the role, if any, of $\mathrm{VC}$ in the transport properties of the components of the examined samples. In this discussion, some boundary conditions should be kept in mind: (i) the measured diffusion coefficients $D$ describe the average contribution to the observed diffusivity of the species involved in aggregationdisaggregation equilibria in a fast exchange on the NMR timescale. (ii) The observed $D$ values are influenced by the hydrodynamic radius of solvated ions. In the specific case of $\left[\mathrm{Li}^{+}\right]$ions, the hydrodynamic radius is affected by the formation of possible aggregates that $\left[\mathrm{Li}^{+}\right]$ions may establish in solution (e.g., with one or more $\left[\mathrm{NTf}_{2}^{-}\right]$anions and possibly with VC). (iii) When comparing the diffusivity in systems without and with VC (e.g., samples 3 vs 4), the background contribution of the viscosity should be considered.

The ratios of the measured diffusion coefficients for each species with and without added VC can be conveniently used to gain information on the role of VC. Table 3 collects the data for the components of IL and for $\left[\mathrm{Li}^{+}\right]$in samples 4 and 3. The viscosity contribution is estimated as the ratio of the viscosity in sample 3 to the viscosity in sample 4, which corresponds to the ratio of the fluidities of samples 4 and 3 .

The first column of Table 3 shows that $D$ (sample 4$) / D$ (sample 3) for $\left[\mathrm{C}_{1} \mathrm{C}_{6} \mathrm{Im}^{+}\right]$shows quite limited fluctuations and, as a first approximation, can be considered constant, thus 
Table 3. Ratio of the Experimental Diffusion Coefficients Determined, for Each Species, in Samples 4 and 3 in the $T$ Range of 305-335 $\mathrm{K}^{a}$

\begin{tabular}{cccccc} 
& \multicolumn{2}{c}{$D$ (sample 4$) / D($ sample 3) } & & $\eta$ (sample 3) $/ \eta$ (sample 4) \\
\cline { 2 - 3 }$T(\mathrm{~K})$ & {$\left[\mathrm{C}_{1} \mathrm{C}_{6} \mathrm{Im}^{+}\right]$} & {$\left[\mathrm{NTf}_{2}^{-}\right]$} & {$\left[\mathrm{Li}^{+}\right]$} & & \\
305 & 1.23 & 1.66 & 1.15 & & 1.63 \\
310 & 1.44 & 1.76 & 1.15 & & 1.59 \\
315 & 1.49 & 1.26 & 1.28 & & 1.56 \\
320 & 1.43 & 1.26 & 1.75 & & 1.53 \\
325 & 1.49 & 1.50 & 1.91 & \\
330 & 1.39 & 1.73 & 1.87 & \\
335 & 1.47 & 1.81 & 1.64 & 1.47 \\
& & &
\end{tabular}

${ }^{a}$ The last column accounts for the viscosity changes upon the dilution of sample 3 with VC.

highlighting a role of "spectator ion" for the imidazolium cation. A different scenario is emerging for $\left[\mathrm{Li}^{+}\right]$and $\left[\mathrm{NTf}_{2}{ }^{-}\right]$. The diffusivity of $\left[\mathrm{Li}^{+}\right]$shows two different regimes for $T<320 \mathrm{~K}$ and $T>320 \mathrm{~K}$. In the former case, the diffusivity gain due to the presence of $\mathrm{VC}$ is below the fluidity gain brought about by the

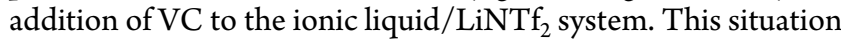
is inversed for $T>320 \mathrm{~K}$, where the $D$ ratio is larger than the corresponding fluidity ratio. This finding is consistent with a specific role of $\mathrm{VC}$ in the transport properties of $\left[\mathrm{Li}^{+}\right]$ions and thus the observed variations of the diffusivity of $\left[\mathrm{Li}^{+}\right]$ions without and with VC cannot be entirely ascribed to macroscopic effects linked to viscosity changes. Additionally, this result is coherent with the enhancement of conductivity discussed in the previous section and with its relationship with the viscosity changes observed upon the dilution with VC. Finally, the enhanced diffusivity of $\left[\mathrm{Li}^{+}\right]$at high temperature in the presence of $\mathrm{VC}$ is very much consistent with the theoretical predictions reported by Deshpande et al. for $\mathrm{N}$-methyl- $\mathrm{N}$-propylpyrrolidinium $\left[\mathrm{NTf}_{2}{ }^{-}\right]$in the presence of VC by molecular dynamics. ${ }^{34}$ The diffusivity data for $\left[\mathrm{NTf}_{2}{ }^{-}\right]$shows a more complex trend: decreasing diffusivity with $T$ for $T<320 \mathrm{~K}$ and the opposite for $T$ $>320 \mathrm{~K}$. A detailed description of such trend is beyond the focus of this work. It is sufficient to observe here that for the $T>320 \mathrm{~K}$ regime, $\mathrm{NTf}_{2}{ }^{-}$behaves similarly to $\left[\mathrm{Li}^{+}\right]$, thus indicating that VC inhibits the coordination of $\mathrm{Li}^{+}$with the anion of the IL. This conclusion is also supported by the literature data on [1-methyl3-ethylimidazolium $]\left[\mathrm{NTf}_{2}\right]$ doped with $\left[\mathrm{LiNTf}_{2}\right]$ salt and in the presence of ethylene carbonate (EC) or VC: the Raman spectra showed an increased intensity of the vibration bands assigned to free $\left[\mathrm{NTf}_{2}^{-}\right]$in the presence of carbonate. ${ }^{33,35}$

The activation energy for diffusivity was calculated experimentally using the diffusion coefficients obtained in the 305$335 \mathrm{~K}$ temperature range. The diffusion data of all of the samples reasonably followed the Arrhenius law, with only two exceptions (see below). The activation energies were calculated from the plots of $\ln (D)$ versus $T^{-1}$ (Figures $2 a-d$ ). The results of the linear fittings are reported in Table 4 . The $E_{\mathrm{a}}$ for the diffusion of $\left[\mathrm{Li}^{+}\right]$deserves a comment. In the case of sample 3, we considered the linear approximation acceptable. The calculated activation energy, however, is affected by a larger uncertainty compared to those of the imidazolium cations and the $\left[\mathrm{NTf}_{2}{ }^{-}\right]$ anions because of the low $\gamma$ value of ${ }^{7} \mathrm{Li}$. In the case of sample 4 (Figure $2 \mathrm{~d}$ ), the uncertainty is even larger. Consequently, the calculated $E_{\mathrm{a}}$ should be considered cautiously, as it provides only a semiquantitative indication.

In the pure $\left[\mathrm{C}_{1} \mathrm{C}_{6} \mathrm{Im}\right]\left[\mathrm{NTf}_{2}\right]$ (sample 1 ), Figure $2 \mathrm{a}$, the cation and the anion show similar activation energies, ${ }^{36}$ and this

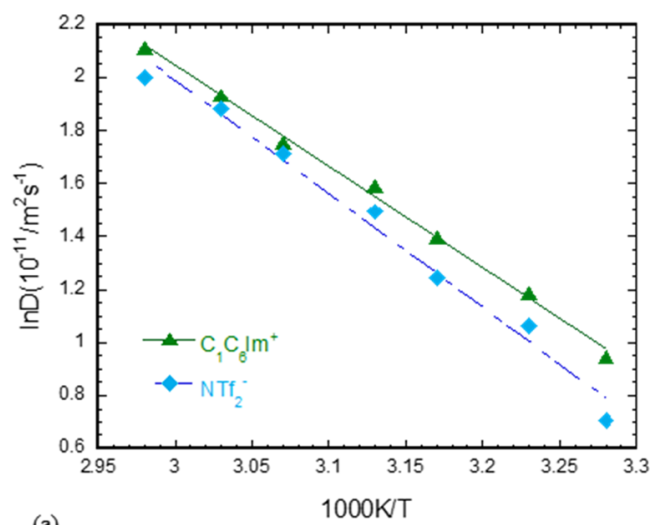

(a)

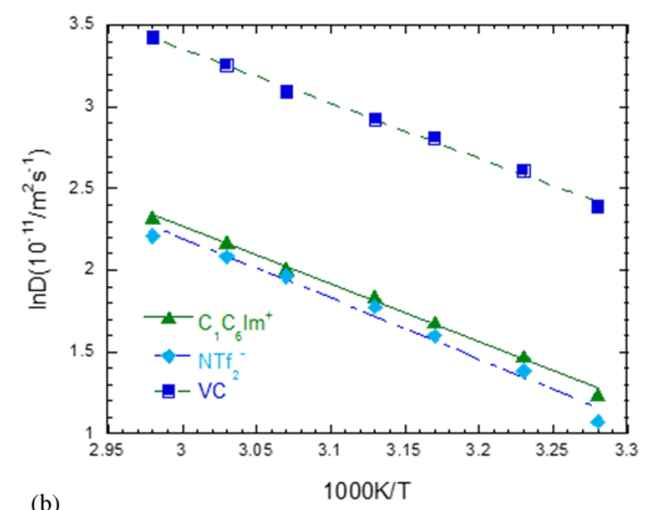

(b)

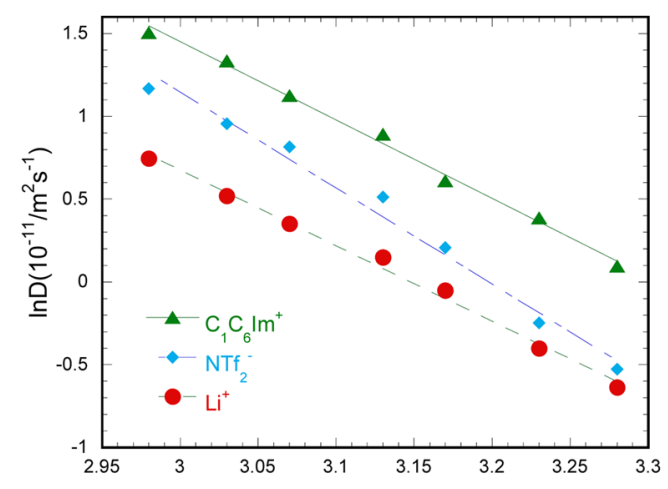

(c)

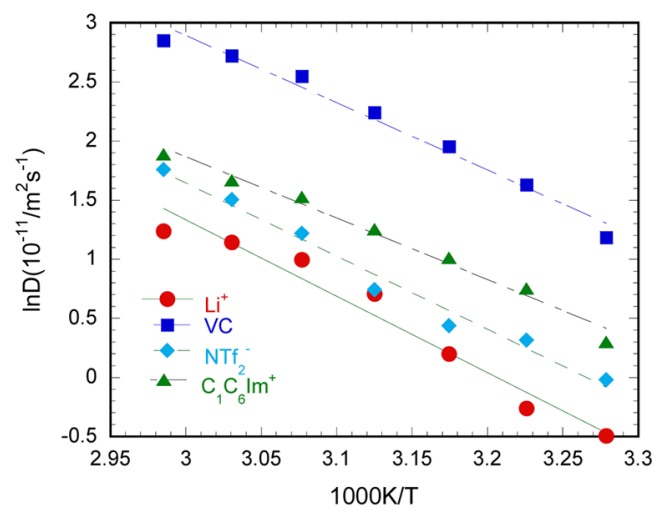

(d)

Figure 2. Arrhenius plot of the motion of $\mathrm{Li}^{+},\left[\mathrm{C}_{1} \mathrm{C}_{6} \mathrm{Im}^{+}\right]$, $\left[\mathrm{NTf}_{2}^{-}\right]$, and VC ions in (a) sample 1: $\left[\mathrm{C}_{1} \mathrm{C}_{6} \mathrm{Im}\right]\left[\mathrm{NTf}_{2}\right]$, (b) sample 2: [ $\left.\mathrm{C}_{1} \mathrm{C}_{6} \mathrm{Im}\right]$ $\left[\mathrm{NTf}_{2}\right] / / \mathrm{VC}(5 \% \mathrm{vol}),(\mathrm{c})$ sample 3: $\left[\mathrm{C}_{1} \mathrm{C}_{6} \mathrm{Im}\right]\left[\mathrm{NTf}_{2}\right] / / \mathrm{LiNTf}_{2}(1$ mol L $\left.{ }^{-1}\right)$, and (d) sample 4: $\left[\mathrm{C}_{1} \mathrm{C}_{6} \operatorname{Im}\right]\left[\mathrm{NTf}_{2}\right] / / \mathrm{VC}(5 \% \mathrm{vol}) / / \mathrm{LiNTf}_{2}$ $\left(1 \mathrm{~mol} \mathrm{~L}^{-1}\right)$. 
Table 4. Activation Energies $E_{\mathrm{a}}\left(\mathrm{KJ} \mathrm{mol}^{-1}\right)$ for the Diffusion of All of the Ions in Samples 1-4

$\begin{array}{lcccc} & \text { sample 1 }\left[\mathrm{C}_{1} \mathrm{C}_{6} \mathrm{Im}\right] & \text { sample 2 } & \text { sample 3 } \\ {\left[\mathrm{NTf}_{2}\right]} & {\left[\mathrm{C}_{1} \mathrm{C}_{6} \mathrm{Im}\right]\left[\mathrm{NTf}_{2}\right] / / \mathrm{VC}(5 \% \mathrm{vol})} & 30 & 39 \\ {\left[\mathrm{C}_{1} \mathrm{C}_{6} \mathrm{Im}^{+}\right]} & 32 & 30 & 45 & 42 \\ {\left[\mathrm{NTf}_{2}{ }^{-}\right]} & 36 & 31 & 40 & 50 \\ \mathrm{Li}^{+} & & & 52^{a} \\ \mathrm{VC} & & 28 & 46\end{array}$

${ }^{a}$ The value is affected by a large uncertainty and should be considered as a semiquantitative indication.

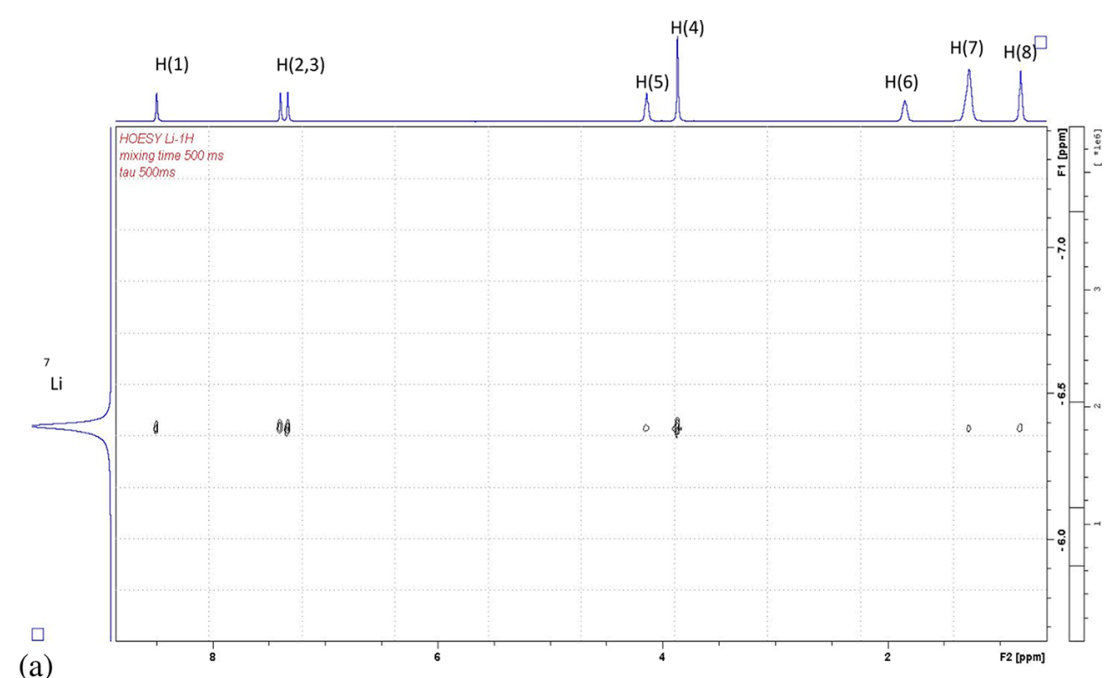

(a)
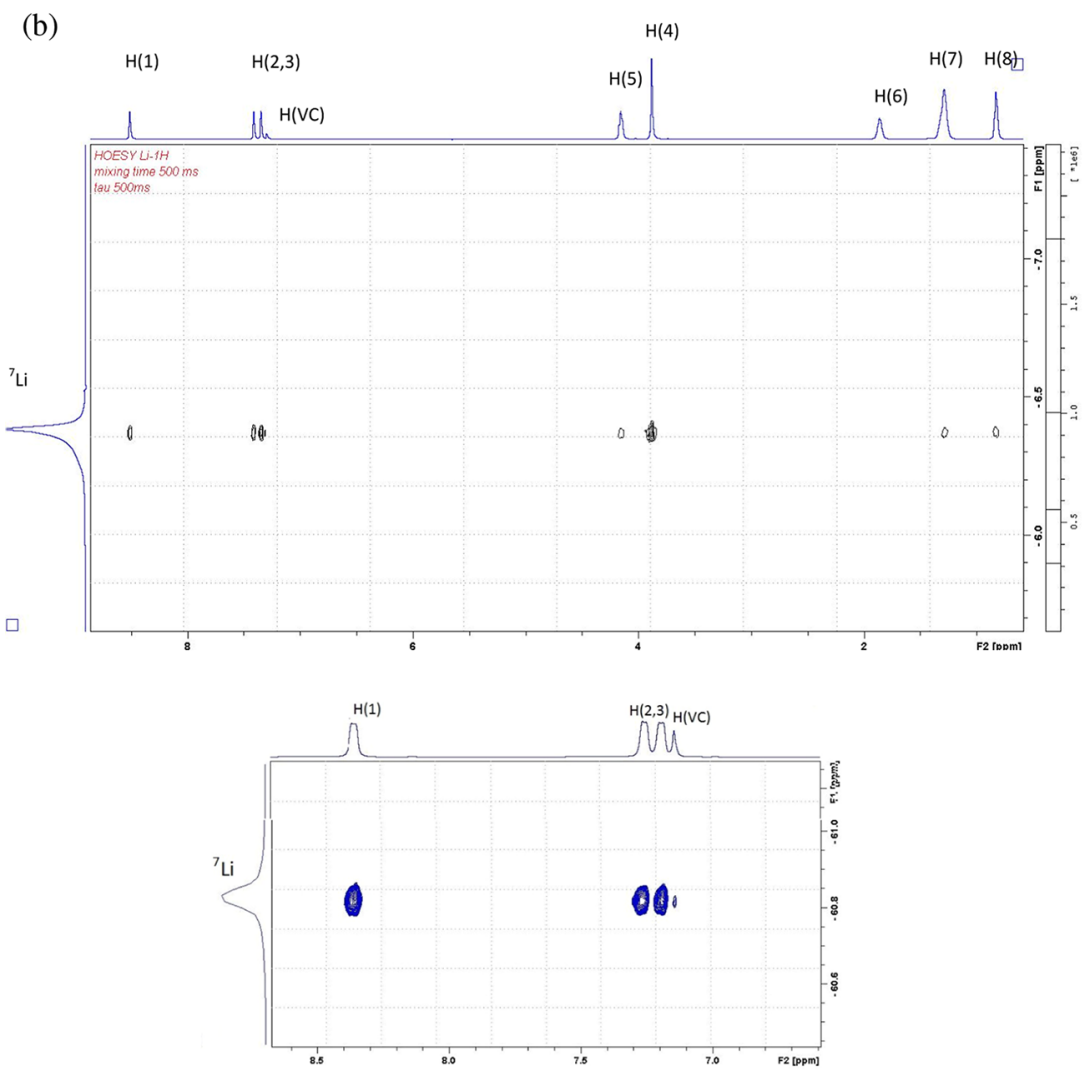

(c)

Figure 3. $\left\{{ }^{7} \mathrm{Li}-{ }^{1} \mathrm{H}\right\}$ HOESY experiment of (a) sample 3: $\left[\mathrm{C}_{1} \mathrm{C}_{6} \mathrm{Im}\right]\left[\mathrm{NTf}_{2}\right] / / \mathrm{LiNTf}_{2}\left(1 \mathrm{~mol} \mathrm{~L}^{-1}\right)$, (b) sample 4: $\left[\mathrm{C}_{1} \mathrm{C}_{6} \mathrm{Im}\right]\left[\mathrm{NTf} f_{2}\right] / / \mathrm{VC}(5 \% \mathrm{vol}) / /$ $\operatorname{LiNTf}_{2}\left(1 \mathrm{~mol} \mathrm{~L}^{-1}\right)$, and $(\mathrm{c})$ expanded aromatic region of the experiment $(\mathrm{b})$.

behavior is also retained with the addition of $\mathrm{VC}$ in $\left[\mathrm{C}_{1} \mathrm{C}_{6} \mathrm{Im}\right]\left[\mathrm{NTf}_{2}\right] / / \mathrm{VC}$ (sample 2 ), Figure $2 \mathrm{~b}$, consistent with a diffusion mechanism largely independent of the presence of the co-solvent. 
In the solution of $\left[\mathrm{C}_{1} \mathrm{C}_{6} \mathrm{Im}\right]\left[\mathrm{NTf}_{2}\right] / / \mathrm{LiNTf}_{2}$ (sample 3 ), Figure $2 c$, both ions of the ionic liquid have a higher activation energy compared to that of neat IL. The activation energy of $\left[\mathrm{C}_{1} \mathrm{C}_{6} \mathrm{Im}^{+}\right]$is lower than that of $\left[\mathrm{Li}^{+}\right]$. This could be related to the restructuring of the anions around $\left[\mathrm{Li}^{+}\right]$, resulting in an increase of the coordination number of $\left[\mathrm{Li}^{+}\right]$.

In $\left[\mathrm{C}_{1} \mathrm{C}_{6} \mathrm{Im}\right]\left[\mathrm{NTf}_{2}\right] / / \mathrm{VC}(5 \%$ vol $) / / \mathrm{LiNTf}_{2}$ solution (sample 4), Figure $2 \mathrm{~d}$ and Table $4, E_{\mathrm{a}}$ for the diffusion of VC is $46 \mathrm{KJ} \mathrm{mol}^{-1}$. This value should be compared to the corresponding one in sample 2 , namely $28 \mathrm{KJ} \mathrm{mol}^{-1}$. The larger value measured in sample 4 for $\mathrm{VC}$ diffusion is comparable to that of $\left[\mathrm{NTf}_{2}^{-}\right]$anion in the same sample which, in turn, is close to the approximate value obtained for $\left[\mathrm{Li}^{+}\right]$diffusion. These findings point toward the presence of aggregation or clustering of the $\left[\mathrm{Li}^{+}\right], \mathrm{VC}$, and $\left[\mathrm{NTf}_{2}{ }^{-}\right]$components, also suggesting the presence of $\mathrm{VC}$ in the coordination sphere of $\left[\mathrm{Li}^{+}\right]^{32}$ Consistently, $E_{\mathrm{a}}$ for $\left[\mathrm{C}_{1} \mathrm{C}_{6} \mathrm{Im}^{+}\right]$is less affected by the presence of $\mathrm{VC}$, in agreement with interaction mainly involving the other components.

NOESY and HOESY Experiments. ${ }^{1} \mathrm{H}-{ }^{1} \mathrm{H}$ NOESY experiments have been performed on samples 3 and 4 , $\left[\mathrm{C}_{1} \mathrm{C}_{6} \mathrm{Im}\right]\left[\mathrm{NTf}_{2}\right] / / \mathrm{LiNTf}_{2}\left(1 \mathrm{~mol} \mathrm{~L} \mathrm{~L}^{-1}\right)$ and $\left[\mathrm{C}_{1} \mathrm{C}_{6} \mathrm{Im}\right]-$ $\left[\mathrm{NTf}_{2}\right] / / \mathrm{VC}(5 \% \mathrm{vol}) / / \mathrm{LiNTf}_{2}\left(1 \mathrm{~mol} \mathrm{~L}^{-1}\right)$, respectively.

Homonuclear ${ }^{1} \mathrm{H}-{ }^{1} \mathrm{H}$ NOESY experiment allows the observation of through-space intermolecular as well as intramolecular NOE connectivities. An expansion of the NOESY experiment on sample 4 (Figure SI-7) shows that the VC protons interact slightly with the alkyl chain of $\left[\mathrm{C}_{1} \mathrm{C}_{6} \mathrm{Im}^{+}\right]$, while no significant interaction is observed with the imidazolium aromatic protons. Moreover, heteronuclear $\left\{{ }^{7} \mathrm{Li}-{ }^{1} \mathrm{H}\right\}$ NOE correlation experiments (HOESY) show dipolar contacts between selected protons of $\left[\mathrm{C}_{1} \mathrm{C}_{6} \mathrm{Im}^{+}\right]$cation and the lithium ion. The experiments performed on sample 3 (Figure $3 \mathrm{a}$ ) and sample 4 (Figure $3 \mathrm{~b}$ ) highlight for both samples a stronger correlation between $\left[\mathrm{Li}^{+}\right]$cation and the protons of the imidazolium ring than with the protons of the alkyl side chain. The results are consistent with the hypothesis that $\left[\mathrm{Li}^{+}\right]$cation is closer to the polar part of the imidazolium cation.

Additionally, $\left\{{ }^{7} \mathrm{Li}-{ }^{1} \mathrm{H}\right\}$ HOESY of sample 4 (Figure $3 \mathrm{c}$, expansion) shows a weak interaction between the $\mathrm{VC}$ proton and $\left[\mathrm{Li}^{+}\right]$cation, consistent with the proximity of $\mathrm{VC}$ and $\left[\mathrm{Li}^{+}\right]$ through a progressive displacement of $\left[\mathrm{NTf}_{2}{ }^{-}\right]$anions in the first $\left[\mathrm{Li}^{+}\right]$solvation shell by the oxygen atoms of $\mathrm{VC}$. $^{13,37}$

Thus, by $\left\{{ }^{7} \mathrm{Li}-{ }^{1} \mathrm{H}\right\}$ HOESY experiments, the VC vicinity with $\left[\mathrm{Li}^{+}\right]$was observed in sample 4, providing an evidence for the formation of $\mathrm{Li}-\mathrm{VC}$ aggregates. This is also consistent with the diffusion data discussed in the previous section, where VC and $\left[\mathrm{Li}^{+}\right]$showed an activation energy for the diffusivity similar to that of $\left[\mathrm{NTf}_{2}^{-}\right]$anion.

Molecular Dynamics Simulation. An atomistic configuration with the same composition of sample 4 was simulated using molecular dynamics as was described in the Experimental and Theoretical Methods section.

Density. Densities from MD are listed in Table SI-6 and in Figure SI-8 along with available experimental measurements. The MD simulations yield densities within about $2.5 \%$ of the available experimental data, indicating that the force field predicts the density of the multicomponent system correctly (Figure SI-4 and Table SI-3).

Self-Diffusion Coefficient. The self-diffusion coefficients of ions of sample 4 were calculated at different temperatures (Table 5) from the mean-squared displacement of the center of mass of each ion using the Einstein relation, eq 3
Table 5. Diffusion Coefficients, $D$, of Ionic and Molecular Species in Sample 4, $\left[\mathrm{C}_{1} \mathrm{C}_{6} \mathrm{Im}\right]\left[\mathrm{NTf}_{2}\right] / / \mathrm{VC}(5 \% \mathrm{vol}) / /$ $\mathrm{Li}\left[\mathrm{NTf}_{2}\right]\left(1 \mathrm{~mol} \mathrm{~L}^{-1}\right)$, at Different Temperatures Calculated from Molecular Dynamics Simulations Using Ionic Charges of $\mathbf{\pm 0 . 8}$ (Experimental Values at $\mathbf{3 1 5} \mathrm{K}$ )

\begin{tabular}{|c|c|c|c|c|}
\hline \multirow[b]{2}{*}{$T(\mathrm{~K})$} & \multicolumn{4}{|c|}{$D\left(10^{-11} \mathrm{~m}^{2} \mathrm{~s}^{-1}\right)$} \\
\hline & {$\left[\mathrm{Li}^{+}\right]$} & $\mathrm{VC}$ & {$\left[\mathrm{NTf}_{2}^{-}\right]$} & {$\left[\mathrm{C}_{1} \mathrm{C}_{6} \mathrm{Im}^{+}\right]$} \\
\hline 315 & 0.28 & 4.5 & 0.69 & 1.0 \\
\hline 335 & $1.1(1.22)$ & $6.7(7.5)$ & $1.6(1.55)$ & $2.4(2.7)$ \\
\hline 355 & 2.4 & 8.4 & 3.9 & 4.8 \\
\hline
\end{tabular}

$$
\left.D=\frac{1}{6} \lim _{t \rightarrow \infty} \frac{\mathrm{d}}{\mathrm{d} t}\left\langle\sum_{i=1}^{N} \vec{r}_{i}(t)-\vec{r}_{i}(0)\right]^{2}\right\rangle
$$

The trend in self-diffusivity is that $D\left[\mathrm{Li}^{+}\right]<D\left[\mathrm{NTf}_{2}^{-}\right]<$ $D\left[\mathrm{C}_{1} \mathrm{C}_{6} \mathrm{Im}^{+}\right]$is consistent with the results of NMR spectroscopy. The computed self-diffusivity of the IL mixture tends to be lower than the experimental values by the equivalent of a $20 \mathrm{~K}$ temperature shift. The small-sized $\left[\mathrm{Li}^{+}\right]$cation has the slowest diffusivity because of the strong interactions with $\left[\mathrm{NTf}_{2}{ }^{-}\right]$.

Radial Distribution Function. We began analysis of the microscopic structure of sample 4 by calculating various atomatom radial distribution functions (RDFs), $g(r)$, together with coordination numbers, $n(r)$, that allow the quantification of the local solvation shells. Coordination numbers were calculated from the area under the radial distribution function, multiplied by the density and $4 \pi r^{2}$. The RDF of $\left[\mathrm{Li}^{+}\right]$with the $\mathrm{O}$ atoms of the anion at $355 \mathrm{~K}$ is plotted in Figure 4.

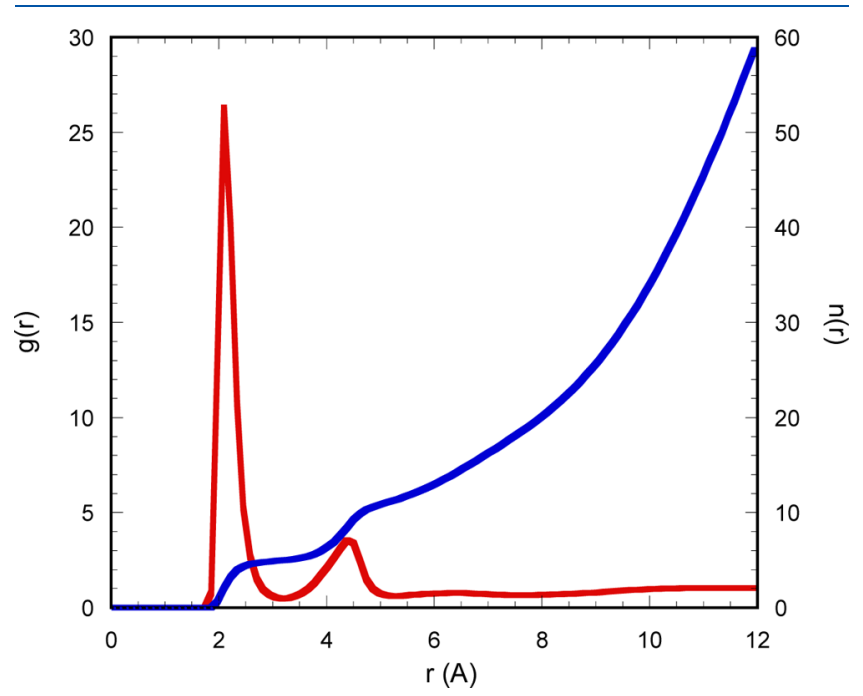

Figure 4. Atom-atom radial distribution function and coordination number of $\mathrm{Li}^{+}-\mathrm{O}_{\mathrm{NTf}_{2}}$ in $\left[\mathrm{C}_{1} \mathrm{C}_{6} \mathrm{Im}\right]\left[\mathrm{NTf}_{2}\right] / / \mathrm{VC}(5 \% \mathrm{vol}) / / \mathrm{Li}\left[\mathrm{NTf}_{2}\right]$, sample 4 , at $355 \mathrm{~K}$. The red lines represent $g(r)$, and the blue lines represent $n(r)$.

$\left[\mathrm{Li}^{+}\right]$cation is closely approached by the $\mathrm{O}$ atoms of $\left[\mathrm{NTf}_{2}{ }^{-}\right]$, $\mathrm{O}_{\mathrm{NTF}_{2}}$, which are the most-exposed negatively charged atoms of the anion, with an intense first peak at $2.1 \AA$, implying a strong correlation between $\left[\mathrm{Li}^{+}\right]$and $\mathrm{O}_{\mathrm{NTf}_{2}}$. The coordination number at a distance of the minimum after the first peak, that is, up to $3.2 \AA$, reaches a value of 4.5 , which indicates the number of $\mathrm{O}_{\mathrm{NTf}_{2}}$ atoms from the anion in the first coordination shell of $\left[\mathrm{Li}^{+}\right]$. 
In sample 3 (no $\mathrm{VC}$ ), the equivalent first peak of the $\mathrm{RDF}$ between $\left[\mathrm{Li}^{+}\right]$and $\mathrm{O}_{\mathrm{NTf}_{2}}$ is at $1.92 \AA$ with an intensity of 29 , with a coordination number of $4.8 \mathrm{O}_{\mathrm{NTf}_{2}}$ around $\left[\mathrm{Li}^{+}\right]$. Likewise, Borodin et al. reported that upon the addition of $20 \%$ ethylene carbonate (EC) to IL electrolyte, the $\mathrm{Li}-\mathrm{O}_{\mathrm{NTF}_{2}}$ coordination number was reduced from 4.8 to 4.5 . $^{13,14}$

These results can be related to the presence of the carbonate molecules $\left(\mathrm{O}_{\mathrm{VC}}\right)$ around $\left[\mathrm{Li}^{+}\right]$competing with the anion $\left(\mathrm{O}_{\mathrm{NTf}_{2}}\right)$. The second peak at $4.3 \AA$ is due to the correlation between $\left[\mathrm{Li}^{+}\right]$and other oxygen atoms of the same anion that contribute to the first peak.

Figure 5 shows the site-site $\mathrm{RDF}$ between $\left[\mathrm{Li}^{+}\right]$and the nitrogen atom of the anion, and the coordination number after

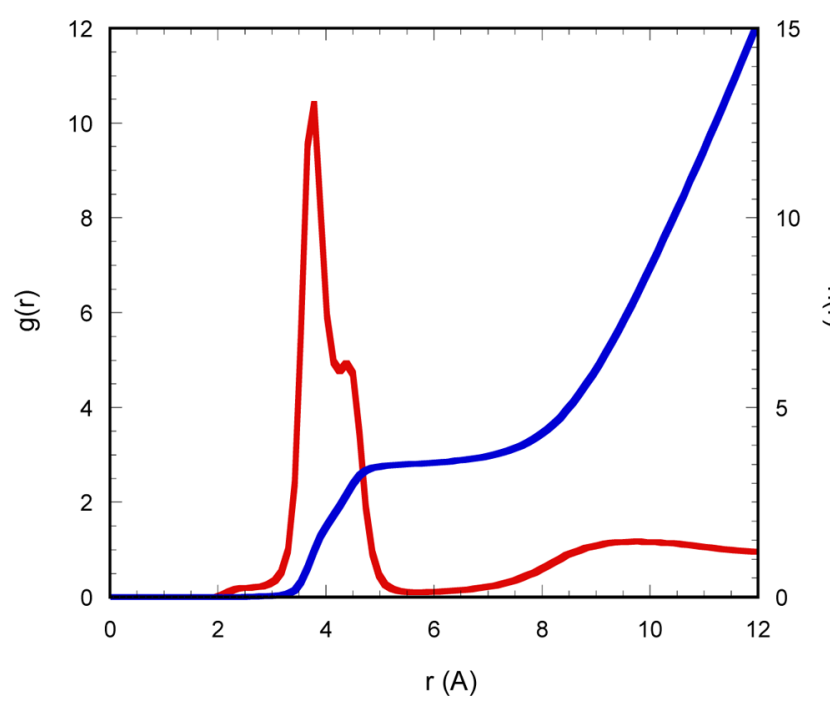

Figure 5. Atom-atom radial distribution function and coordination number function of $\mathrm{Li}-\mathrm{N}_{\mathrm{NTF}_{2}}$ in $\left[\mathrm{C}_{1} \mathrm{C}_{6} \mathrm{Im}\right]\left[\mathrm{NTf}_{2}\right] / / \mathrm{VC}(5 \% \mathrm{vol}) / /$ $\mathrm{Li}\left[\mathrm{NTf}_{2}\right]$ at $355 \mathrm{~K}$. The red lines represent $g(r)$, and the blue lines represent $n(r)$.

the first peak is $3.5 \mathrm{~N}_{\mathrm{NTf}_{2}}$ atoms in the first coordination shell of $\left[\mathrm{Li}^{+}\right]$. Taken together with the coordination numbers relative to the $\mathrm{O}_{\mathrm{NTf}_{2}}$ atoms of the anion around $\left[\mathrm{Li}^{+}\right]$, this allows us to conclude that on an average $3.5\left[\mathrm{NTf}_{2}{ }^{-}\right]$anions coordinate with each $\left[\mathrm{Li}^{+}\right]$cation in either a bicoordinated (with two $\mathrm{O}_{\mathrm{NTf}_{2}}$ atoms) or a monocoordinated structure with $\left[\mathrm{Li}^{+}\right]$cation. ${ }^{13}$

In electrolytes based on carbonate, $\left[\mathrm{Li}^{+}\right]$cation was preferentially solvated by carbonyl rather than ethereal oxygen of carbonate. ${ }^{15}$ To study the interaction between $\mathrm{VC}$ and $\left[\mathrm{Li}^{+}\right]$, $\mathrm{RDF}$ and coordination number of the carbonyl $\mathrm{O}$ atom of $\mathrm{VC}$, $\mathrm{O}_{\mathrm{VC}}$, around $\left[\mathrm{Li}^{+}\right]$cation are plotted in Figure 6.

The very intense strong first peak of the RDF between $\left[\mathrm{Li}^{+}\right]$ and $\mathrm{O}_{\mathrm{VC}}$ at $2.1 \AA$ Andicates a high probability of finding these two atom types at close separations. The coordination number shows that the number of neighbors in the first coordination shell is 0.5 , instead of $0.8\left(60\left[\mathrm{Li}^{+}\right]\right.$and $\left.48 \mathrm{VC}\right)$, a result consistent with the low decrease of the coordination number 4.8 to $4.5 \mathrm{O}_{\mathrm{NTf}_{2}}$ around $\left[\mathrm{Li}^{+}\right]$in the presence of VC. Very high first peaks in RDFs, such as in this case, are due, in large part, to a dilution effect. The average probability of finding a pair of $\left[\mathrm{Li}^{+}\right]-\mathrm{O}_{\mathrm{VC}}$ in the solution is small because of their low concentrations. Therefore, when they are associated in the respective solvation shells, the peak in the RDF becomes very

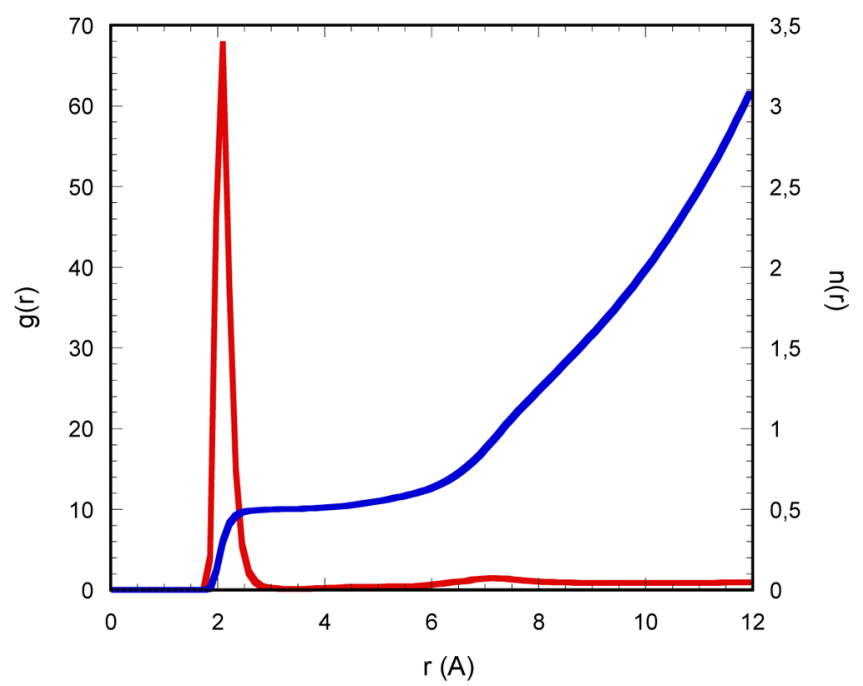

Figure 6. Atom-atom radial distribution function and coordination number of $\mathrm{Li}-\mathrm{O}_{\mathrm{VC}}\left(\right.$ carbonyl O) in $\left[\mathrm{C}_{1} \mathrm{C}_{6} \mathrm{Im}\right]\left[\mathrm{NTf}_{2}\right] / / \mathrm{VC}(5 \% \mathrm{vol}) / /$ $\mathrm{Li}\left[\mathrm{NTf}_{2}\right]$ at $355 \mathrm{~K}$. The red lines represent $g(r)$, and the blue lines represent $n(r)$.

intense (a RDF measures the likelihood of finding a pair of atoms at a certain distance with respect to the average density of those pairs in the entire system). The opposite occurs for the components of the solution that are in majority, such as atoms from $\left[\mathrm{C}_{1} \mathrm{C}_{6} \mathrm{Im}^{+}\right]$and $\left[\mathrm{NTf}_{2}^{-}\right]$ions.

In analogous recent results, ${ }^{37}$ in $\mathrm{N}$-methyl- $\mathrm{N}$-propylpyrrolydinium bis(trifluoromethanesulfonyl)imide ( $\left[\mathrm{C}_{3} \mathrm{C}_{1} \mathrm{py}\right]$ $\left.\left[\mathrm{NTf}_{2}\right]\right) / / \mathrm{LiNTf}_{2} / / \mathrm{OA}$ electrolyte, it was proved that the partial negative charges on the oxygen atoms of organic additives (EC, VC, and tetrahydrofuran) facilitated the discoordination of $\mathrm{O}_{\mathrm{NTf}_{2}}$ from the coordination shell of $\left[\mathrm{Li}^{+}\right]$cation, reducing the extent of cluster formation.

An alternative way to examine the local structure is through spatial distribution functions (SDFs), where the distribution and number of adjacent molecules are represented by isosurfaces of specific density values. We calculated SDFs for $\left[\mathrm{Li}^{+}\right]$cations around $\left[\mathrm{NTf}_{2}{ }^{-}\right]$anions and also around $\mathrm{VC}$, as shown in Figure 7 . Around $\left[\mathrm{NTf}_{2}{ }^{-}\right]$anion, there are several regions of the (a)

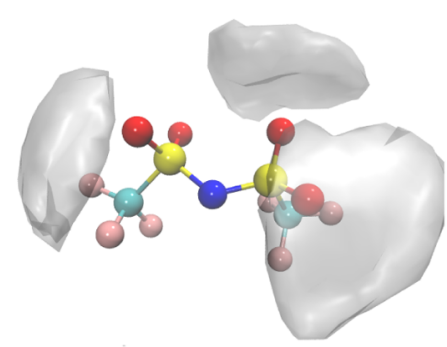

(b)

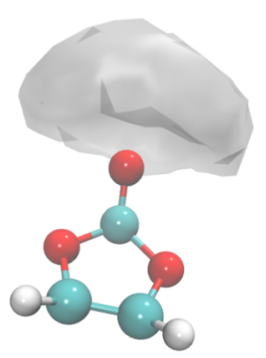

Figure 7. Spatial distribution function of $\mathrm{Li}^{+}$ions around (a) $\mathrm{NTf}_{2}{ }^{-}$ anion and $(\mathrm{b}) \mathrm{VC}$ in $\left[\mathrm{C}_{1} \mathrm{C}_{6} \mathrm{Im}\right]\left[\mathrm{NTf}_{2}\right] / / \mathrm{VC}(5 \% \mathrm{vol}) / / \mathrm{Li}\left[\mathrm{NTf}_{2}\right]$. The density isosurfaces correspond to values of 6 and 4 times the average density of $\mathrm{Li}^{+}$, respectively.

presence of $\left[\mathrm{Li}^{+}\right]$cation near the different $\mathrm{O}_{\mathrm{NTf}_{2}}$ atoms. As published, ${ }^{15}$ around $\mathrm{VC}$ molecule, $\left[\mathrm{Li}^{+}\right]$cation is a single highly localized cation in a region around the $\mathrm{VC}$ carbonyl $\mathrm{O}$, meaning that the interaction is directional with VC. Together with the very intense first peaks of the RDF, which show that the local density of $\left[\mathrm{Li}^{+}\right]-\mathrm{O}_{\mathrm{VC}}$ pairs in the first solvation shell is over 60 
times the average density, the SDFs confirm highly localized positions of $\left[\mathrm{Li}^{+}\right]$in the first solvation shell of $\mathrm{VC}$.

\section{CONCLUSIONS}

With ionic-liquid-based electrolytes, the intercalation-deintercalation of $\left[\mathrm{Li}^{+}\right]$in Cgr electrodes is mainly observed in the presence of VC. The aim of this work was to determine whether $\mathrm{VC}$ has a role in the solvation and/or in the transportation of $\left[\mathrm{Li}^{+}\right]$cation in the electrolyte $\left[\mathrm{C}_{1} \mathrm{C}_{6} \mathrm{Im}\right]\left[\mathrm{NTf}_{2}\right] / / \mathrm{VC}(5 \%$ $\mathrm{vol}) / / \mathrm{Li}\left[\mathrm{NTf}_{2}\right]\left(1 \mathrm{~mol} \mathrm{~L}{ }^{-1}\right)$ electrolyte to further understand the specific properties of batteries in its presence.

From $\left\{{ }^{7} \mathrm{Li}-{ }^{1} \mathrm{H}\right\}$ HOESY experiment and MD calculations, the vicinity of $\mathrm{VC}$ with $\left[\mathrm{Li}^{+}\right]$cation was proved. From the RDF calculation, five oxygens were found around $\left[\mathrm{Li}^{+}\right]$corresponding to $3.5\left[\mathrm{NTf}_{2}{ }^{-}\right]$anions in a bicoordinated or a monocoordinated structure. The VC oxygen was located at $2.1 \AA$, like the oxygens from $\left[\mathrm{NTf}_{2}{ }^{-}\right]$anions, in the first coordination shell of $\left[\mathrm{Li}^{+}\right]$with a very intense strong first peak of the RDF. VC is capable to scavenge the $\left[\mathrm{Li}^{+}\right]$cations away from the $\left[\mathrm{NTf}_{2}{ }^{-}\right]$anions with an average of $0.5 \mathrm{O}_{\mathrm{VC}}$ atoms around $\left[\mathrm{Li}^{+}\right]$, that is, providing a mixture of $\left[\mathrm{Li}^{+}\left(\mathrm{NTf}_{2}\right)_{n}\right]^{(n-1)-}$ and $\left[\mathrm{Li}^{+}\left(\mathrm{NTf}_{2}\right)_{(3.5)}(\mathrm{VC})_{(0.5)}\right]^{m-}$ in the $\left[\mathrm{C}_{1} \mathrm{C}_{6} \mathrm{Im}\right]\left[\mathrm{NTf}_{2}\right] / / \mathrm{VC}(5 \% \mathrm{vol}) / / \mathrm{Li}\left[\mathrm{NTf}_{2}\right]$ electrolyte mixture. This potential formation of $\mathrm{a}\left[\mathrm{Li}^{+}\right]-\mathrm{O}_{\mathrm{VC}}$ interaction/ coordination is also consistent with our diffusion data, where VC and $\left[\mathrm{Li}^{+}\right]$showed an activation energy for the diffusivity similar to that of $\left[\mathrm{NTf}_{2}^{-}\right]$anion. The $\left[\mathrm{Li}^{+}\right]-\mathrm{O}_{\mathrm{VC}}$ interaction/ coordination could explain the VC influence on the performances of the graphite secondary batteries with an ionic-liquidbased electrolyte since (i) the diffusion coefficient of $\left[\mathrm{Li}^{+}\right]$is expected to increase because of the larger diffusivity of $\mathrm{VC}$ compared to that of $\left[\mathrm{NTf}_{2}^{-}\right]$anion and (ii) the activation energy for $\left[\mathrm{Li}^{+}\right]$diffusion is likely to increase, due to a somewhat morecomplicated diffusion mechanism based on Borodin's work, passing through $\mathrm{Li}-\left[\mathrm{NTf}_{2}^{-}\right]$complex diffusion, disruption, $\left[\mathrm{Li}^{+}\right]-\mathrm{VC}$ complex formation, and so forth.

\section{ASSOCIATED CONTENT}

\section{S Supporting Information}

The Supporting Information is available free of charge on the ACS Publications website at DOI: 10.1021/acs.jpcb.8b05231.

Fitting of the experimental signal decay; calculated and experimental densities and enthalpy of vinylene carbonate vaporization; density as a function of temperature of investigated samples; viscosity and Arrhenius plot parameters $(\mathrm{PDF})$

\section{AUTHOR INFORMATION}

\section{Corresponding Authors}

*E-mail: andrea.mele@polimi.it (A.M.).

*E-mail: catherine.santini@univ-lyon1.fr (C.C.S.).

\section{ORCID}

Agílio A. H. Pádua: 0000-0002-7641-6526

Catherine C. Santini: 0000-0002-3070-4848

\section{Notes}

The authors declare no competing financial interest.

\section{ACKNOWLEDGMENTS}

E.W. thanks the Dipartimento di Chimica, Materiali e Ingegneria Chimica “G. Natta”, Politecnico di Milano, Via L. Mancinelli 7, 20131 Milano, Italy for COST EXIL1206 for STSM.

\section{REFERENCES}

(1) Park, J.-K. Principles and Applications of Lithium Secondary Batteries; Wiley-VCH: Weinheim, 2012.

(2) Armand, M.; Endres, M.; MacFarlane, D. R.; Ohno, H.; Scrosati, B. Issues and challenges facing rechargeable lithium batteries. Nat. Mater. 2009, 8, 621-629.

(3) Passerini, S.; Henderson, W. A. Secondary Batteries - Lithium Rechargeable Systems I Electrolytes: Ionic Liquids. Encycl. Electrochem. Power Sources 2009, 85-91.

(4) Lewandowski, A.; Swiderska-Mocek, A. Ionic liquids as electrolytes for Li-ion batteries: An overview of electrochemical studies. J. Power Sources 2009, 194, 601-609.

(5) Diaw, M.; Chagnes, A.; Carre, B.; Willmann, P.; Lemordant, D. Mixed Ionic Liquid as Electrolyte for Lithium Batteries. J. Power Sources 2005, 146, 682-684.

(6) Holzapfel, M.; Novak, P.; Jost, C. Stable cycling of graphite in an ionic liquid based electrolyte. Chem. Commun. 2004, 2098-2099.

(7) Holzapfel, M.; Novak, P.; Prodi-Schwab, A.; Krumeich, F.; Wursig, A.; Buqa, H.; Novák, P. Stabilisation of lithiated graphite in an electrolyte based on ionic liquids: an electrochemical and scanning electron microscopy study. Carbon 2005, 43, 1488-1498.

(8) Sato, T.; Maruo, T.; Marukane, S.; Takagi, K. Ionic Liquids Containing Carbonate Solvent as Electrolytes for Lithium Ion Cells. J. Power Sources 2004, 138, 253-261.

(9) Guerfi, A.; Dontigny, M.; Charest, P.; Petitclerc, M.; Lagace, M.; Vijh, A.; Zaghib, K. Improved Electrolytes for Li-ion Batteries: Mixtures of Ionic Liquid and Organic Electrolyte with Enhanced Safety and Electrochemical Performance. J. Power Sources 2010, 195, 845-852.

(10) Srour, H.; Rouault, H.; Santini, C. C. Imidazolium-based ionic liquid electrolytes for Li-ion secondary batteries based on graphite and LiFePO4. J. Electrochem. Soc. 2013, 160, A66-A69.

(11) Lassègues, J. C.; Grondin, J.; Talaga, D. Lithium Solvation in Bis(trifluoromethanesulfonyl) imide-based Ionic Liquids. Phys. Chem. Chem. Phys. 2006, 8, 5629-5632.

(12) Bayley, P. M.; Best, A. S.; MacFarlane, D. R.; Forsyth, M. The Effect of Coordinating and Non-coordinating Additives on the Transport Properties in Ionic Liquid Electrolytes for Lithium Batteries. Phys. Chem. Chem. Phys. 2011, 13, 4632-4640.

(13) Li, Z.; Borodin, O.; Smith, G. D.; Bedrov, D. Effect of Organic Solvents on $\mathrm{Li}+$ Ion Solvation and Transport in Ionic Liquid Electrolytes: A Molecular Dynamics Simulation Study. J. Phys. Chem. B 2015, 119, 3085-3096.

(14) Borodin, O.; Smith, G. D.; Henderson, W. $\mathrm{Li}^{+}$Cation Environment, Transport, and Mechanical Properties of the LiTFSI Doped N-Methyl-N-alkylpyrrolidinium TFSI Ionic Liquids. J. Phys. Chem. B 2006, 110, 16879-16886.

(15) Bogle, X.; Vazquez, R.; Greenbaum, S.; von Wald Cresce, A.; Xu, $\mathrm{K}$. Understanding $\mathrm{Li}^{+}$-Solvent Interaction in Nonaqueous Carbonate Electrolytes with ${ }^{17} \mathrm{O}$ NMR. J. Phys. Chem. Lett. 2013, 4, 1664-1668.

(16) Bolimowska, E.; Morales-Ugarte, J. E.; Rouault, H.; Santos-Pena, J.; Santini, C.; Benayad, A. Influence of the Vinylene Carbonate on the Wetting and Interface Chemical Structure of Doped Ionic Liquid Electrolyte at Porous Graphite Surface. J. Phys. Chem. C 2017, 121, 16166-16173.

(17) Morales-Ugarte, J. E.; Bolimowska, E.; Rouault, H.; Santos-Pena, J.; Santini, C. C.; Benayad, A. EIS and XPS Investigation on SEI Layer Formation During First Discharge on Graphite Electrode With a Vinylene Carbonate Doped Imidazolium Based Ionic Liquid Electrolyte. J. Phys. Chem. C 2018, 18223-18230.

(18) Burrell, A. K.; Sesto, R. E. D.; Baker, S. N.; McCleskey, T. M.; Baker, G. A. The large scale synthesis of pure imidazolium and pyrrolidinium ionic liquids. Green Chem. 2007, 9, 449-454.

(19) Almantariotis, D.; Gefflaut, T.; Pádua, A. A. H.; Coxam, J. Y.; Costa Gomes, M. F. Effect of fluorination and length of the alkyl sidechain on the solubility of carbon dioxide in 1-alkyl-3-methylimidazolium bis(trifluoromethylsulfonyl)amide ionic liquids. J. Phys. Chem. B 2010, 114, 3608-3617.

(20) Canongia Lopes, J. N.; Costa Gomes, M. F.; Husson, P.; Pádua, A. A. H.; Rebelo, L. P. N.; Sarraute, S.; Tariq, M. Polarity, viscosity and 
ionic conductivity of liquid mixtures containing $\left[\mathrm{C}_{4} \mathrm{C}_{1} \mathrm{im}\right]\left[\mathrm{NTf}_{2}\right]$ and a molecular component. J. Phys. Chem. B 2011, 115, 6088-6099.

(21) Allen, M. P.; Tildesley, D. J. Computer Simulations of Liquids; Clarendon: Oxford, U.K., 1987.

(22) Breneman, C. M.; Wiberg, K. B. Determining Atom-Centered Monopoles From Molecular Electrostatic Potentials - the Need for High Sampling Density in Formamide Conformational-Analysis. J. Comput. Chem. 1990, 11, 361-373.

(23) (a) Jorgensen, W. L.; Maxwell, D. S.; Tirado-Rives, J. Development and Testing of the OPLS All-Atom Force Field on Conformational Energetics and Properties of Organic Liquids. J. Am. Chem. Soc. 1996, 118, 11225-11236. (b) Cornell, W. D.; Cieplak, P.; Bayly, C. I.; Gould, I. R.; Merz, K. M.; Ferguson, D. M.; Spellmeyer, D. C.; Fox, T.; Caldwell, J. W.; Kollman, P. A. A second generation force field for the simulation of proteins, nucleic acids, and organic molecules. J. Am. Chem. Soc. 1995, 117, 5179-5197.

(24) (a) Canongia Lopes, J. N.; Deschamps, J.; Padua, A. A. H. Modeling ionic liquids using a systematic all-atom force field. J. Phys. Chem. B 2004, 108, 2038-2047. (b) Canongia Lopes, J. N.; Padua, A. A. H. CL\&P: A generic and systematic force field for ionic liquids modeling. Theor. Chem. Acc. 2012, 131, No. 1129.

(25) Martínez, L.; Andrade, R.; Birgin, E. G.; Martínez, J. M. Packmol: A package for building initial configurations for molecular dynamics simulations. J. Comput. Chem. 2009, 30, 2157-2164.

(26) Plimpton, S. J. Fast parallel algorithms for short-range molecular dynamics. J. Comput. Phys. 1995, 117, 1-19.

(27) Bhargava, B. L.; Balasubramanian, S. Refined potential model for atomistic simulations of ionic liquid $[\mathrm{bmim}]\left[\mathrm{PF}_{6}\right]$. J. Chem. Phys. 2007, 127, No. 114510.

(28) Ahosseini, A.; Weatherley, L. R.; Scurto, A. M. Viscosity and Diffusivity for the Ionic Liquid 1-Hexyl-3-methyl-imidazolium Bis(trifluoromethylsulfonyl)amide with 1-Octene. J. Chem. Eng. Data 2011, 56, 3715-3721.

(29) Castiglione, F.; Moreno, M.; Raos, G.; Famulari, A.; Mele, A.; Appetecchi, G. B.; Passerini, S. Structural organization and transport properties of novel pyrrolidinium based ionic liquids with perfluoroalkyl sulfonylimide anions. J. Phys. Chem. B 2009, 113, 10750-10759.

(30) D’Agostino, C.; Mantle, M. D.; Mullan, C. L.; Hardacre, C.; Gladden, L. F. Diffusion, Ion Pairing and Aggregation in 1-Ethyl-3Methylimidazolium-Based Ionic Liquids Studied by ${ }^{1} \mathrm{H}$ and ${ }^{19} \mathrm{~F}$ PFG NMR: Effect of Temperature, Anion and Glucose Dissolution. ChemPhysChem 2018, 19, 1081-1088.

(31) Umebayashi, Y.; Hamano, H.; Seki, S.; Minofar, B.; Fujii, K.; Hayamizu, K.; Tsuzuki, S.; Kameda, Y.; Kohara, S.; Watanabe, M. Liquid structure of and Li+ Ion Solvation in Bis(trifluoromethanesulfonyl)-amide Based Ionic Liquids Composed of 1-ethyl-3-methylimidazolium and $\mathrm{N}$-methyl-N-propylpyrrolidinium Cations. J. Phys. Chem. B 2011, 115, 12179-12191.

(32) Castiglione, F.; Ragg, E.; Mele, A.; Appetecchi, G. B.; Montanino, M.; Passerini, S. \|Molecular Environment and Enhanced Diffusivity of $\mathrm{Li}^{+}$Ions in Lithium-Salt-Doped Ionic Liquid Electrolytes. J. Phys. Chem. Lett. 2011, 2, 153-157.

(33) Duluard, S.; Grondin, J.; Bruneel, J.-L.; Pianet, I.; Grelard, A.; Campet, G.; Delville, M.-H.; Lassegues, J.-C. Lithium Solvation and Diffusion in the 1-Butyl-3-methylimidazolium Bis(trifluoromethansulfonil)imide Ionic Liquid. J. Raman Spectrosc. 2008, 39, 627-632.

(34) Deshpande, A.; Kariyawasam, L.; Dutta, P.; Banerjee, S. Enhancement of Lithium Ion Mobility in Ionic Liquid Electrolytes in Presence of Additives. J. Phys. Chem. C 2013, 117, 25343-25351.

(35) Hardwick, L. J.; Holzapfel, M.; Wokaun, A.; Novak, P. Raman Study of Lithium Coordination in EMI-TFSI Additives Systems as Lithium Ion Battery Ionic Liquid Electrolytes. J. Raman Spectrosc. 2007, $38,110-112$.

(36) Castiglione, F.; Moreno, M.; Raos, G.; Famulari, A.; Mele, A.; Appetecchi, G. B.; Passerini, S. Pyrrolidinium-Based Ionic Liquids Doped with Lithium Salts: How Does Li Coordination Affect Its Diffusivity? J. Phys. Chem. B 2009, 113, 10750-10759.
(37) von Zamory, J.; Giffin, G. A.; Jeremias, S.; Castiglione, F.; Mele, A.; Paillard, E.; Passerini, S. Influence of oligo(ethylene oxide) substituents on pyrrolidinium-based ionic liquid properties, $\mathrm{Li}^{+}$ solvation and transport. Phys. Chem. Chem. Phys. 2016, 18, 21539. 